\title{
Analytical Studies about the Bioceanic Corridor
}

\author{
Estudios analíticos acerca del Corredor Bioceánico \\ Estudos analíticos sobre o Corredor Bioceânico
}

\author{
João Carlos Parkinson de Castro ${ }^{1}$ \\ Received on 16 Aug. 2021; revised and approved on 28 Sept. 2021; accepted on 13 Oct. 2021 \\ DOI: http://dx.doi.org/10.20435/inter.v22i4.3484
}

\section{INTRODUCTION}

The project of the Bio-Oceanic Road Corridor is multidimensional and multi-sectoral, which demands a holistic vision and a fluid and comprehensive coordination from national coordinators. Given these characteristics, the analysis identify strengths and weaknesses that impact the strategic development of the project, as well as offers elements that allow national authorities to transform an infrastructure work into an economic development platform, capable of changing local reality, promoting inclusive growth, generating quality jobs and diversifying productive activity.

This analytical approach also allows national policy makers to prioritize actions that are necessary, as it identifies the strengths or strong points of the project and alerts national authorities about the existence of weaknesses or threats, so that the country's strategic planning can be adjusted accordingly.

Due to the wide territorial coverage and the diversity of situations, the analysis of the Bioceanic Road corridor was divided into four sections, namely the northern provinces of Chile, the Argentine Northwest (Noa), the Paraguayan Chaco region and the Brazilian Midwest.

\section{ORTHERN PROVINCES OF CHILE}

\subsection{Strengths}

\subsubsection{Well-developed logistics and port infrastructure}

Northern Chile has a modern port system, a wide network of border crossings and good rail and road connections. Its ports are able to receive large vessels (Angamos Port), have weekly services to Asia and to West Coast of the USA, customs clearance is usually fast and their retro areas have enough space for the construction of warehouses and modern logistics platforms.

According to the" Linear Shipping Connectivity Index (LSCI)", Chile would have the best port services (42), followed by Brazil (38) and Argentina (35) ${ }^{2}$. The Port of Mejillones, specialized in the movement of solid and liquid bulk (6 million tons in 2017), has a natural depth of 16.5 meters, which allows it to receive vessels of 90,000 tons. The Port of Angamos, is also authorized to receive Pos-Panamax ships. On the other hand, Argentine ports have limitations of draught and maritime frequency and those in Brazil have accessibility deficiencies as well as face slow port transits.

\footnotetext{
1 Ministério das Relações Exteriores, Brasília, Distrito Federal, Brasil.

2 United Nations Conference on Trade and Development (Unctad). Available at: https://www.ceicdata.com/en/ indicator/brazil/liner-shipping-connectivity-index.
} 
From the South American continent, Chilean ports can be accessed by highway (routes, 27, 23, 25 and 5) or by rail (Ferronor, Paso de Socompa). The Chilean railway integrates, in Salta, with the Argentine railway network (Belgrano Cargas), which represents an important advantage for Chile and Argentina. Northern Chile is therefore connected with north of Argentina by three road passes, Jama (4275 mts), Sico (4092 mts) and Socompa (3875 mts). In this sense, road and rail connections tend to mitigate logistical impact created by the high heights of the Northern Andes.

\subsubsection{Business environment and economic and commerce dynamism}

Chile has developed several clusters, namely: mining (Antofagasta), fruit grapes and olive oil (Coquimbo), wines (Valparaíso), fruits, honey, wood and salmon (Strait of Magellan and southern Chile). It therefore features varied production, good business environment, modern infrastructure and efficient logistics. There is therefore an institutional structure and physical infrastructure that encourages product processing and value aggregation. There is only lack of scale, so that domestic and foreign investors become interested in financing productive projects.

The Chilean economy grew steadily for many years and its trade policy enables preferential access to international markets. The country has negotiated 26 bilateral and multilateral trade agreements, comprising $64 \%$ of the world's population and $86 \%$ of global GDP. Such a network of trade agreements can stimulate productive integration and the international marketing of processed inputs, provided that rules of origin are respected.

\subsubsection{Alternative route for Brazilian, Argentine and Paraguayan trade}

The maritime connection of Chile with Peru, Ecuador and Colombia and with the West Coast of the USA, allows Brazilian, Argentine and Paraguayan cargo to flow by highway to a Chilean port and then to various destinations in the Pacific (North-South Pacific dorsal Corridor), representing convenient logistical alternative to the current routes frequently congested (cost of the Atlantic Ocean).

\subsubsection{Operational advantages}

It is possible to transport cargo by highway to Antofagasta (2 days) and embark a ship bound for Shanghai (35 days), exploring the accesses to the North and South Transpacific corridors. The sea route will last an average of 37 days. The advantages of this logistic alternative lie in avoiding the congestion of the Port of Santos, Paranaguá or Buenos Aires and eliminating the time of loading and unloading in these ports (7 days or more). This logistics solution is also favored by a higher maritime frequency of Chilean ports ( 3 to 4 boats per week) and lower freight (US 1,520 for a 20-foot container, on the Antofagasta-Shanghai route, against US 2,170 on the SantosShanghai stretch) (CASTRO, 2020).

\subsection{Weaknesses}

\subsubsection{High altitudes raise transport costs}

Chile has 38 passes along the border with Argentina, but the highest are precisely those of Jama (4200 mts) and Sico (4092 mts), both located on the Capricorn axis. There are passes in 
the south of the country that are only 10 meters above sea level, such as San Sebastian, but they are far from the Bio-Oceanic Road Corridor. The Andes Mountain loses altitude as it advances towards the south. The altitude of the border crossings is an important weakness of the BioOceanic Corridor.

The advantages resulting from the cost and time reduction are affected by the altitude of the Jama and Sico passes, which causes greater fuel consumption, greater wear of the undercarriage, low speed, as well as limits the volume of cargo and the size of truck. Given these restrictions, it is necessary that the benefits of geographical distance are maintained or even increased through effective logistical gains and greater operational efficiency. As topography is a relevant obstacle, value-added cargo and the use of containers should be preferred.

\subsubsection{Low integration between Chilean logistics services and Brazilian, Argentine and Paraguayan companies}

Despite the quality of Chilean port services, the integration of Argentine-BrazilianParaguayan producers and Chilean ports-shipping companies are still fragile. It is not enough that the Chilean ports have draft and space for new warehouses and logistics platforms. The guarantee of frequency, the value of sea freight, the availability of space on vessels, competitive port services, the existence of cold refrigeration capacity, the availability of storages areas, competitive port tariffs and other measures are necessary to promote an effective integration between Chilean Port and Argentine, Brazilian and Paraguayan producers. However, regional exchange is highly dependent on maritime transport and shipping routes which are determined not by trade or port operators but by the shipping companies themselves.

As it lies at the western end of the Bioceanic Road Corridor, Chile will only attract commercial operators if it is able to ensure agility, efficiency and competitiveness in the movement of cargo at their ports and across the four national borders. Currently, half of Chilean exports are destined to the Asian continent and the sea route is the most used (97\%). In future, this situation will need to be adjusted.

The integration of customs systems at border crossings and the adoption of logistical measures that reduce costs and provide speed in the control processes of foreign trade operations will be crucial, so that the expectations generated by the opening of the corridor will not be thwarted.

The ports of Arica and Iquique attract the interest of foreign investors and international operators. However, the absence of an air connection between Antofagasta and Campo Grande hinders regular and direct access, which does not contribute to business development. Currently, an air trip from Campo Grande to Arica can last 17 to 18 hours, with stops in São Paulo and Santiago. The Bio-Oceanic Road corridor makes it possible to advance Road integration, but it is also necessary to integrate railway networks and establish direct air connections.

\subsubsection{Specialization and limitations of logistics services}

The port of Angamos (3.7 million tons) and the Northern Bulk Terminal (2.8 million tons), which make up the Mejillones port complex, are owned by CODELCO. Because they specialize in the movement of mineraks notably copper ore, they do not have the same experience nor have they achieved the same efficiency as Atlantic ports in handling agricultural bulk. 
The railway integration by Socompa allows the movement of solid bulk. However, as the pass is at an altitude of 3,876 meters, trains are limited, with compositions of 9 to 11 wagons. It is therefore necessary to improve railroad layout and increase the average speed in order to offer a more competitive average fare per kilometer. For the movement of containers, it is possible to increase the number of wagons of the railroad composition.

Although Antofagasta region has four public port terminals, which moved in 2019, 13.5 million tons (mostly copper and only $22 \%$ of general cargo), exports from these ports $(14.2 \%$ of the total exported by Chile) are strongly concentrated in Asia (62.4\%). Only 4.3\% of the total exports from Antofagasta were bound to South America. This reality is reflected in higher sea freights and tower supply of vessels. The concentration of foreign trade activity in Asia and in few and large companies are important weaknesses.

\subsubsection{Chilean exports do not take advantages of the Bio-Oceanic Road Corridor}

The vast majority of Chilean exports (60\%) get into Brazil by sea: port of San Francisco, Santos and Paranaguá. In case the goods are destined to Campo Grande, it will be necessary to cover an additional distance of $1.097 \mathrm{~km}$. When the entrance takes place by road, if it is by São Borja or Uruguaiana, the distances traveled are, respectively, 1,381 km and 1,556 km. The road sections are extensive and expensive, penalizing the consumer of the Brazilian Midwest.

\section{NORTH OF ARGENTINA}

\subsection{Strenghts}

\subsubsection{Mediterranean location encourages the increase of trade relations not only with Chile but also with Paraguay and Brazil}

The Bio-Oceanic Road corridor should not only be seen as a means of outflow of Argentine ore to Chile and, by extension, to the Asian market. It is possible to transport Brazilian cargo to Salta (2-3 days), pack it in containers and dispatch it to Mejillones or Port of Angamos, bound for Shanghai (35 days) (CASTRO, 2020). The corridor also creates favorable conditions for exports to the West Coast of the USA, a traditional destination for South American exports. Physical integration and the improvement of local logistics will favor the attraction of investments and the development of productive integration projects (for example, the transformation of fruits into juices or grains into oil) with the creation of new quality jobs.

\subsubsection{It currently has a railway network already established}

It is only necessary to improve current conditions and reintegrate the network to Bolivia (reconstruction of two bridges) to make it possible to move cargo by rail between Buenos Aires-Salta-Campo Grande. The improvement of the traffic conditions of Belgrano cargos and the Argentina-Bolivia-Brazil railway integration would give scale to the transport of bulk cargo, enable a more competitive freight and implement in the North of Argentina a quality regional logistics, which would attract investments and compensate for the current high logistics costs.

In addition, the Salta-Antofagasta railway connection is a reality (Ferronor). The Chilean company is allowed to use the Argentine network up to Salta. The $905 \mathrm{~km}$ of railway lines are 
covered in 42 hours by a train of weekly frequency. In 2017, the railway transported 8.3 million tons. The increase in cargo capacity and the improvement of the route would stimulate the use of the railway modal, enabling Argentine exports of ore through Chilean ports (lithium, copper, silver, lead, boron, cesium and gold), as well as general cargo from Brazil and Paraguay. At present, North of Argentina alone has 32 mining projects under exploration or execution, 18 of which are in advanced state.

\subsubsection{There are natural resources in abundance, diverse sources of energy (gas, wind, solar, oil) and a young labor force}

We have the best conditions for the organization of clusters and value addition, as well as for the development of export axes of energy surpluses to the other territories of the Corridor. Given the possibility of abundant and cheap energy, the North of Argentina could import inputs, transform them into higher value-added products and allocate them for export to the Asian market and other territories in the Corridor. It could also envisage selling energy surplus to Mato Grosso do Sul.

\subsection{Weaknesses}

\subsubsection{Mediterranean nature and distance from major centres}

The Mediterranean condition of the territory requires coordination with other national and international jurisdictions, as well as the undertaking of investments for improving logistics services, in order to stren gth physical connectivity with nearby territories (Plan de Logística de la Provincia de Salta [CONSEJO ECONÔMICO SOCIAL, 2016]).

The geographical distance between Salta/Jujuy, the existence of scattered consumption centers, some infrastructure and logistical deficiencies impose high transport costs for companies in northern Argentina, which burdens the movement of cargo- notably intra- seasonal flowsand discourages productive investments in the North of Argentina. Low production density, low trade volume and passing traffic have a negative impact on the quality of logistics services and operational efficiency.

According to CEDOL, logistics costs rose, in general, more than transport costs, which evidently compromised the demand for transport. This situation greatly harms the north of Argentina because it is located farther from major consumption centers (Banco Mundial, oct. 2010).

\subsubsection{Dominance of road modal and limitation of carriers}

The dominance of road modal is a hindrance, as it does not favor the movement of bulk cargo at competitive prices. The scarce network of local transport companies, the low number of freight distribution centers, logistics platforms, warehouses and the low integration of transport modes do not favor efficient logistics or the use of multimodality. As a result, the offer of transport services is practically reduced to the movement of cargo by highway, subject to high freight, volatility of the price of diesel, the risk of theft and expensive insurance, as well as fleet deficiency and difficulty in identifying return cargo.

INTERAÇÕES, Campo Grande, MS, v. 22, n. 4, p. 1061-1076, out./dez. 2021. 
The road network can still be expanded, and it is necessary to pave some secondary routes to allow the flow of generated cargo in isolated production centers. Besides, the predominance of road transport for grain exports and the coincidence of the region's harvest seasons cause high transport costs.

Competition with Chilean and Brazilian carriers can be a source of tension and commercial harm for local carriers. The formation of partnerships between transport companies of different nationalities and cargo sharing are solutions that must be explored. The use of freight exchanges between local companies and the development of truck consortia are other possibilities that can be explored in order to ensure better conditions for local companies in cargo competition with more efficient carriers.

Finally, the big cities of north of Argentina (Salta, Jujuy and Tucumán) are not very far away (on average $300 \mathrm{~km}$ ), which would facilitate the redistribution of cargo by local carriers. The generation of a regular annual flow of cargo could alleviate the plight of smaller transport companies, as it would give them work throughout the year.

\subsubsection{Digital deficit}

In Northern Argentina, telecommunications network coverage is low, making it difficult to monitor the cargo in real time as well as digital integration of customs documentation control and processing services.

\subsubsection{North-South load flow concentration}

The production structure of Salta/Jujuy, strongly based on primary products, and the absence of large consumer centers near the north of Argentina cause a concentration of cargo flows with a strong north-south orientation. Since the production of Salta/Jujuy is mostly primary and the small local factory park acquires few productive inputs, the cargo volumes of the SouthNorth direction tend, necessarily, to be always smaller than those of the north-south direction (BANCO MUNDIAL, 2010). This situation creates difficulties for the movement of goods on round trips, burdens the road service and penalizes small and medium producers. The aggregation of value in the North of Argentina, from the transformation of local resources or imported inputs, could compensate for this structural imbalance.

\subsubsection{Rail Transport still poor and little use of waterway}

Despite the latest investments, the rail service can still improve its performance, so as to attract greater cargo volume and offer more competitive freight, reducing the high logistics costs caused by the geographical distance from large consumption centers and the lack of alternatives for transporting locally generated cargo at harvest time. On average, rail freight is equivalent to $50 \%$ to $65 \%$ of road freight in high season or $20 \%$ in low season. The improvement of rail transport would represent a substantive change in the level of competitiveness of the north of Argentina. The dry port of Perico (Jujuy) should be used as a center for cargo transfers, development of the maquila and warehouse of goods, in order to take advantage of the Belgrano Cargas network and proximity of Jujuy airport. Similarly, the use of the Port of Barranqueras and the Paraguay-Paraná waterway for grain flow would be a logistical option to be also explored. 
If works are not carried out to improve the capacity and performance of Belgrano cargos, road transport will continue to be an attractive solution for meeting deadlines, since a trip by rail from Las Lajitas to Rosario lasts 4 to 6 days, versus 24 to 36 hours if it is by truck.

\subsubsection{Weaknesses in trade integration with Chile}

The productive sector of northern Argentina is not integrated with the port services of neighboring countries, which generates uncertainty and high costs. Agreements with shipping companies for the retention and use of containers (dry and refrigerated) and the possibility of the cargo being exported from Salta and sent directly to the Chilean ports with control only at the final destination are initiatives that could stimulate the aggregation of value and the generation of employment in Salta/Jujuy.

Since the cargo exported by Argentina to Chile is predominantly of primary products, the containers, when used, tend to be those of 20". However, Argentina and Chile import valueadded goods usually transported in $40^{\prime \prime}$ containers. Therefore, the decision on what to export and where to export is, in reality, conditioned on the availability of containers at the times and volumes convenient for the operator. It happens, however, that containers belong to the shipping companies, which make them available according to their interests, which are not always aligned with those of producers and exporters.

\subsubsection{Weaknesses of road transport when the final destination is the Brazilian Midwest}

In the case of Argentine exports entering Brazil by land, 93\% of the flows reach Brazilian territory through mainly two customs, namely, São Borja (49\%) and Uruguaiana (20\%). In case they are destined to Campo Grande, they must travel $1.171 \mathrm{~km}$ and $1353 \mathrm{~km}$ respectively, to be available. The product loses competitiveness due to high logistics cost. In the event that the product enters São Borja and is destined to Sorriso, a city of high purchasing power of Mato Grosso; the distance to be covered would be $2.282 \mathrm{~km}$.

\section{PARAGUAYAN CHACO}

\subsection{Strengths}

\subsubsection{Open and dynamic economy}

The Paraguayan economy has historically been one of the most open in the region, a consequence of a productive model based on the export of commodities and the import of manufactured products and capital goods not produced locally. The implementation of the Bioceanic Road corridor will make the participation of foreign trade in Paraguay's GDP even higher, generating more quality jobs and diversification of productive sectors and sustained growth. The external sector tends to gain even more dynamism and confirm its condition as the main engine of the country's economy.

\subsubsection{Trade focusing on Corridor countries}

Although economic forecasts indicate that the Brazilian economy is expected to show low growth and that the Argentine economy will face its second year of recession, Paraguay-Argentina 
trade grew $72 \%$ in 2019. In the case of Paraguayan exports to Argentina, the variation was striking: an increase of $261 \%$. This spectacular performance was achieved without the infrastructure of the Bioceanic Road Corridor, which reveals the enormous trade and investment potential that has not yet been exploited and that will receive strong stimulus when the highway connects Paraguay in the east-west direction and logistics services are attracting cargo from other routes or even generating new trade flows.

The Paraguay-Chile exchange is also expected to grow significantly. Currently, in the specific case of meat imports from Chile, $94 \%$ of foreign purchases of this product originate from Brazil (37\%), Paraguay (30\%), Argentina (14\%) and the USA (13\%). It is very likely that the corridor and the improvement of the road connection will stimulate Paraguayan exports of meat to Chile and Brazil. Another possibility is access to the dynamic market of the West Coast of the USA not through the Port of Paranaguá, but through Chilean ports.

\subsubsection{Improved access to the Asian market}

Unlike Chile, Paraguay destines 54\% of its exports to South America and only $16 \%$ to Asia. Among the target markets of its foreign sales emerges Russia, the third largest trading partner. In 2017, Paraguay exported U\$ 989 million of meat to Russia, Chile, Brazil, Lebanon, Kuwait, Taiwan, Egypt, Iraq and Israel. China is only relevant as a source of imports, even ahead of Brazil. Given this history, everything leads to believe that Paraguay should explore the Bioceanic Road corridor to increase its exports to the Asian continent, diversifying its trading partners. Paraguayan exports of frozen and chilled meat to Russia are expected to grow significantly, due to the shorter distance and logistical gains generated by the corridor. By reducing the geographical distance that separates the country from the Pacific $(1,167 \mathrm{~km}$ from Pozo Hondo to Antofagasta, a journey to be traveled by truck in two days), Paraguay will also reduce the economic costs and logistics gaps (related services) that keep it away from Asia, ensuring greater competitiveness for its products. It will not be necessary to resort solely to Paranaguá for the disposal of Paraguayan production.

\subsubsection{Waterway experience in grain handling}

With the implementation of the Bioceanic Road Corridor, more bulk cargo will be transported by river ports (waterway network of 1,264 km). The corridor will lead to an increase in the production of Chaco grains, but the best route of runoff will be the waterway. Paraguay has 3 public ports and 41 private terminals. It is therefore in an enviable situation. In addition, unlike the ports of Chile, Paraguayan ports are used to moving agricultural bulk and do not face the barrier of the Andes. The waterway is also the natural alternative for the flow of cargoes from the Midwest Region of Brazil, mainly Mato Grosso do Sul and the micro regions of Mato Grosso, located below the 16th parallel.

\subsubsection{Integration of the Paraguayan territory}

The paving of the Carmelo Peralta-Pozo Hondo route should directly benefit 60,000 and indirectly 170,000 people, inhabitants of the Departments of Presidente Hayes and Boquerón. With the opening of the route, not only will the Bioceanic Road Corridor be practically constituted (only the construction of the Porto Murtinho-Carmelo Peralta bridge would be missing), but 
above all the centuries-old isolation of the Paraguayan Chaco region, an area of enormous agricultural potential, low population density and little manufacturing activity will be broken. The paving of a highway in the vast Chaco region will integrate land that can be quickly adapted to agricultural production. The type of soil is very similar to the Brazilian savannah, an area of large grain production. However, it will be necessary to develop suitable seeds and introduce modern irrigation techniques. Water scarcity is a great challenge, but it can be overcome with the construction of reservoirs, just like what was done by the Melonites.

\subsection{WEAKNESSES}

\subsubsection{Expensive and insufficient logistics}

Poor logistics services and high transport costs discourage investment and attraction of foreign companies. In Latin America and the Caribbean, logistics costs absorb 18\% to 35\% of the value of the product and consume $16 \%$ to $26 \%$ of GDP. By way of comparison, in OCDE countries, the same costs do not exceed, on average, $8 \%$ of the value of the product and do not represent more than $9 \%$ of GDP. Therefore, an important weakness is the precarious logistics of the current Paraguayan transport system (OCDE, 2018).

Despite the progressive advancement of logistics services, the number of officially qualified logistics operators is still scarce. As a result, the supply of logistics services is still limited and, largely, non-specialized. At present, there is a gap between the demand for specialists and the ability of Paraguayan academic centers to provide technicians with good training and in sufficient numbers to meet market demand;

The relevance of logistics services is conditioned by the degree of openness of the economy and the size of the internal market, the number of existing logistics nodes and the interest in exploiting multimodality in freight transport. A country that exports a large part of its production and aims to make full use of transport corridors must necessarily promote the creation of logistics zones close to its main production and consumption centers, at border points, in ports and airports and where cargo disruption occurs. The national transport policy cannot therefore be limited to ensuring connectivity. Should stimulate a multimodal, efficient and modern logistics service, one that do not burden production costs and reap the benefits of preferential tariff cuts.

\subsubsection{Digital deficit}

Broadband penetration in Paraguay is still restricted and the level of document digitization is low. With great frequency, paper is used and human interference occurs, which generates operational inefficiencies. The weakness of the internet signal in the countryside is a weakness that must be overcome in order to make possible the flow by land of perishable products destined to the international market. Perishable products are normally subject to real-time monitoring and traceability.

\subsubsection{Low intermodality}

Despite the Mediterranean condition, Paraguay has not yet been able to articulate multimodal solutions that integrate road, rail, waterway and air network, enabling a regular cargo flow between the Atlantic and Pacific. The Paraguayan transport system is concentrated in 
the road (23\%) and waterway (76\%) modes. The Paraguayan railway network (440 km between Asunción-Encarnación) is a serious weakness for the movement of bulk cargo from production spots to river ports. It is, therefore, necessary to establish future rail connections with Argentina, Brazil and Chile, in order to provide greater competitiveness to general cargo (meat in containers) and Paraguayan agricultural production (bulk). Given the status of a Mediterranean country, the growing Paraguayan production will face difficulties to be transported by the river ports and Paranaguá, if investments are not made to expand the railway network and the river port capacity. Given this framework, the Paraguayan government should resume the project elaborated by Koica or, alternatively, explore other railway projects that ensure integration with neighboring countries.

\subsubsection{Logistics Political Priorization}

In order to offer commercial operators an efficient and modern logistics and create the conditions to consolidate Paraguay as a regional" player", it is necessary to develop a state policy in this field, promote its institutionality and exploit the innovative capacity of the young Paraguayans working in the logistics sector. Logistics cannot be treated as a secondary issue, given the implications for the Bio-Oceanic Road Corridor and the Paraguayan pretensions to implement rail connections with neighboring countries. Likewise, the Paraguayan customs system must become a partner of the productive sector. The fluidity of customs transit will attract investment and create quality jobs, while excessive human interference and unjustified bureaucracy will only take away competitiveness from Paraguayan products and scare away foreign investors and take away the gains from the improved infrastructure;

The creation of a transnational and Bio-Oceanic infrastructure obliges Paraguay to consider logistics and cargo transport in the future as state policies, fully integrated into its economic development policies, so that the country can, in a near future, not only offer modern logistics services, but also implement connectivity of regional and international reach, through the modernization of road routes between Paraguay and Bolivia and railway integration with Argentina, Brazil, Chile and Bolivia. If a few operations are to be carried out (repair of the bridges in the Tartagal and Carapari rivers) and the necessary investments are made to improve performance, it will be possible to connect by railroad Campo Grande to Santa Cruz (1083km), Santa Cruz to Yacuíba (549 km), Yacuíba to Perico and Jujuy $(335 \mathrm{~km})$, a total of 1,967 km of railway tracks. All of them is in metric gauge, not being necessary transshipment.

\subsubsection{Little air integration}

The Antofagasta-Salta-Asunción-Campo Grande air connection, among others, would facilitate the flow of tourists and the accomplishment of the intended investments. Paraguay is in an exceptional situation to develop an important air hub for passenger flights in South America. It should be noted that, at the moment, no airport in the region is among the 30 most important in the world in air cargo. 


\section{MATO GROSSO DO SUL, BRASIL}

\subsection{Strengths}

\subsubsection{Creation of alternative routes and new trade flows, with competitiveness gains}

With the Bio-Oceanic Road Corridor, Chilean, Argentine and Paraguayan products would start to join Brazil by Porto Murtinho, Corumbá and Ponta Porã, that is, not only by the south of Brazil, but also by the Midwest. Therefore, in a position to access competitive prices to the distant markets. Preliminary studies carried out by Empresa de Planejamento e Logística- EPL indicated that the reduction of transport and logistics costs could, in some cases, reach $60 \%$. The Argentine, Paraguayan and Chilean producers would therefore have expressive competitive gains, as well as access to untouched markets (CASTRO, 2020). On the other hand, consumers of the Mid-West would have a cheaper and more diverse basket of products.

According to a study by EPL, with the Bio-Oceanic Road Corridor and the optimization of customs processes, it is estimated to reduce, in time and cost, of, respectively, $67 \%$ and $18 \%$, in a road shift from the Atlantic to the Pacific. In addition to defogging the ports of Santos and Paranaguá, eliminating the onerous passage through the Panama Canal or avoiding the dangerous and unpredictable Strait of Magellan, there will be a reduction of 4 thousand nautical miles or almost twelve days of maritime transport. A trip from Antofagasta to Shanghai lasts 42 days, while a trip from Santos to Shanghai through the Panamá Canal takes 54 days. In addition to accessing Chilean ports in less time, the entrepreneur will have at his disposal a more varied maritime frequency, a more agile and less expensive port transit, as well as more competitive freights (CASTRO, 2020).

\subsubsection{The state of Mato Grosso do Sul has a privileged position and good road connectivity}

The state of Mato Grosso do Sul is located far from the waters of the Atlantic, if viewed from the state perspective. However, if the perspective is South America, Mato Grosso do Sul is positioned in the center of the continent. It is therefore in a privileged logistical position, close to major national markets and major continental consumer centers. Soon, Mato Grosso do Sul can play the role of a redistributive center of inputs and products. Its highways, railways and waterways connect the state to the rest of Brazil and neighboring countries, offering good conditions for the flow of cargo on a large scale;

The state has extensive road connectivity with the rest of the Brazilian territory and neighboring countries. The road sector of Mato Grosso do Sul is integrated into Paraná by the BR-163, which expands in the south-north direction to the municipality of Sonora, bordering the state of Mato Grosso. The BR-267, in turn, connects the state with the north of São Paulo. By BR262, Mato Grosso do Sul is also connected to the East with Espírito Santo and the Atlantic, and to Bolivia and Paraguay to the West. The state is also cut by extensive rail network $(1,300 \mathrm{~km})$, which allows the transport of cargo by way of network West to Bolivia and Paraguay. Through the Rumo Malha Paulista, via the same gauge railway, the Rumo Malha Oeste reaches Mairinque, in Greater São Paulo, and the Port of Santos itself. Rumo Malha Oeste also has a connection with Rumo Malha Norte, which connects Mato Grosso do Sul to Rondonópolis, in Mato Grosso. Therefore, through the railway network of the state you can access the state of São Paulo without passing through the bottleneck of the Port of Santos; 
In addition, Mato Grosso do Sul has $787 \mathrm{~km}$ of the Paraguay-Paraná waterway, being also able to access the Paraná-Tietê waterway, which bathes the states of São Paulo and Paraná. In addition, the implementation of the North Corridor, with the completion of the paving of BR163, would establish a waterway road connection with the north of Brazil through the Tapajós and Amazonas rivers;

Mato Grosso do Sul has high productive potential, a large area for sustainable occupation and low population density. The state therefore has all the characteristics of a territory with a strong export vocation. Successive governments have sought to develop in the state adequate logistics chains to move the generated cargo. Given the central location of its territory, the state also lends itself to redistributing the production generated in neighboring countries through the development of efficient multimodal transport system;

The existing multimodal transport system allows access to the Intermodal Terminal of Campo Grande International Airport, enabled for cargo transport. In addition, it is also planned to implement a dry port in the capital, so that the nationalization of the cargo will be carried out directly in Campo Grande, not being necessary to transit through Santos or Paranaguá, ports that have strong congestion at peak times of the flow of the Brazilian crop;

One of the industrial poles of the State (Export Processing Zone [ZPE]) is being built in the Bataguassu region, a point of convergence between Mato Grosso do Sul, Paraná, São Paulo, Goiânia, Paraguay and Argentina, offering a logistics that combines the waterway, road, rail and air modes. The fluvial Port of Presidente Epitácio is also a possible exit to the ports of Santos and Paranaguá;

The existing infrastructure enables the state to become a redistributive center of cargo originating in Argentina, Chile and Paraguay. There is therefore no reason to continue buying Chilean wine or salmon from intermediaries (transported by air from Santiago to Vira Copos, São Paulo) if the product can be imported and sold directly in Campo Grande and redistributed to more distant markets in the country. For example, despite the high purchasing power, the consumption of Chilean salmon in Sorriso (MT) or Palmas (TO) is still low, consumption centers still not accessible to Argentine, Chilean and Paraguayan producers (total imports of US 22.7 billion, in 2018).

\subsubsection{Enormous agricultural potential, an agro-industrial sector in training and an installed multimodal transport system}

The state of Mato Grosso do Sul has a significant production of soybean ( $5^{\text {th }}$ national producer and $4^{\text {th }}$ exporter), corn ( $4^{\text {rd }}$ producer and $4^{\text {th }}$ exporter), sugar cane $\left(5^{\text {th }}\right.$ producer and $5^{\text {th }}$ exporter), beef ( $3^{\text {nd }}$ producer and $5^{\text {th }}$ exporter), pork ( $8^{\text {th }}$ producer and $6^{\text {th }}$ exporter), chicken meat ( $8^{\text {th }}$ producer and $7^{\text {th }}$ exporter) and pulp ( $1^{\text {st }}$ producer and exporter). Because it has a large area of land $(357,145.534 \mathrm{~km} 2$, sixth state in size), a quarter of the planet's freshwater reserve, low number of inhabitants (2.7 million inhabitants), agricultural production is largely destined to export (US\$ 5.2 billion, in 2019). By moving mainly bulk, a transport system has been developed that has railway, waterway and highway. The large-scale load-handling capacity is therefore installed. It is only necessary to improve transport conditions so that the available modes are used more efficiently (APEX BRASIL, 2020). 


\subsubsection{The corridor stimulates the development of the world's largest pulp pole}

With more than 1 million hectares of eucalyptus planted and annual export of 5.3 million tons of pulp (US\$ 1,9 billion in 2019) to 43 countries, thanks to a high productivity index (39 cubic meters of wood per hectare/year), the producing region of Três Lagoas could benefit from the transport of pulp by highway/railway/waterway. At present, production is transported by rail to the Port of Santos.

\subsubsection{The corridor allows the strengthening of existing industrial segments}

Currently, the state has a cattle herd of 21 million heads ( $4^{\text {th }}$ largest national herd), which has generated foreign exchange revenue of around US\$ 497 million; 22 companies in the sugar sector are responsible for producing ethanol, allowing the state to reduce its energy dependence by producing clean energy. The food and beverage sector (976 companies and revenue of $\mathrm{R} \$$ 2.4 billion) could benefit from the import of cheap inputs and the export of local products. The textile, factory clothing and clothing shops, consisting of 386 companies, can also benefit from the paving of Transchaco, as it can develop partnerships with Paraguayan companies and export to the Asian market products transformed by the activity of maquila.

\subsection{Weaknesses}

\subsubsection{Logistic isolation and difficulties for the flow of the agricultural crop}

The implementation of a transcontinental road infrastructure breaks with the current logistical isolation of the state of Mato Grosso do Sul, penalized for being far from the Atlantic Ocean, which forces local producers to transport their agricultural production to the ports of Santos $(1,057 \mathrm{~km})$ and Paranaguá $(1,097 \mathrm{~km})$, incurring high logistics costs. Last year, Brazil exported 75.3 million tons of soybeans and corn, and 27.9 million tons were handled by Santos and 16.4 million by Paranaguá. The production of Mato Grosso do Sul follows this route and is transported, to a large extent, by highway. Since much of the production of Mato Grosso is also handled by the same ports, only when the so-called North exit is fully operational (road and rail flow through the river and sea ports of northern Brazil) will there be some relief in demand for the use of the southeast corridor for the handling of agricultural production in the state;

The logistics developed by Mercosur favored the Buenos Aires-São Paulo axis, but penalized destinations farther from traditional cargo routes. When transported by highway, Argentine and Chilean cargo enters Brazil through Rio Grande do Sul (São Borja and Uruguaiana), which makes the Midwest, North and Northeast victims of intermediation, cascading taxes and the high cost of freight. The distance from Uruguaiana to Campo Grande (MS) is $1.556 \mathrm{~km}$ and if the final destination is Sorriso (MT), the load will have to travel $2.653 \mathrm{~km}$;

In addition to the need to promote customs integration and the adoption of modern logistics services, the crossing of Jama (4,200 mts) and Sico (4,092 mts) constitutes an important geographical barrier, since it imposes restrictions on the use of the type of truck (for example, large trucks), raises operating costs and restricts access to the days and hours in which atmospheric conditions allow vehicle traffic. These limitations may make it impossible to move solid bulk by road, although they can be circumvented in the case of transport of general cargo (containers) or when there is a transformation of the product at a point along the route and, later, movement by container to the port. 


\subsubsection{High logistical costs}

The logistics costs of Mato Grosso do Sul are well above those practiced by traditional competitors. It has a share of $16 \%$ to $25 \%$ in the final price of the product against $9 \%$, on average, of OCDE countries. South America invests $2.3 \%$ of its GDP per year in infrastructure. It is not enough to narrow the gap that separates us from Asian countries. For products marketed in bulk (grain or ore) and as international prices are established on the stock exchange, the producer's margins end up being very narrow. Any gain in competitiveness due to reduced logistics costs is always welcome. In this sense, the fall in the rate of investment in infrastructure, the reduction in the supply of credit for the construction of works by BNDES, the policy of readjustment of Petrobras fuel prices, the control of the value of road freight and the predominance of road modal in the Brazilian transport system are important weaknesses when it comes to infrastructure and logistics in Brazil. Mato Grosso do Sul ends up being a victim of the lack of investment in infrastructure and the inefficiency of the multimodal transport system.

\subsubsection{Tariff advantages do not compensate for high logistics costs}

The trade preference agreements of ALADI and MERCOSUR, because they do not include alternative logistics solutions, did not create the necessary conditions for the Brazilian product to have a strong presence in the north of Argentina or Chile. Brazilian production is hostage to large consumption centers and loses competitiveness when it is destined for more distant or less traditional markets. In fact, the negotiated tariff advantages do not even compensate for the high costs of road logistics and the long journeys made to ensure the delivery of the product.

\subsubsection{Business constraints on foreign trade}

The lack of modern logistics services and multimodal operators, the low number of" tradings "registered in Mato Grosso do Sul, the small number of local companies with international experience and with experienced employees in dealing with issues related to foreign trade are structural weaknesses that must be faced so that Mato Grosso do Sul can exploit all the benefits of the creation of the Bioceanic Road Corridor;

The northern provinces of Chile and Argentina and the Paraguayan chaco region do not yet have "show-rooms" or commercial representations prepared to answer the questions of entrepreneurs from Mato Grosso do Sul. As a result, access to information about what territories export and import is precarious; there are no samples of products or information about investment opportunities. The deficit of mutual knowledge and trade information is a major weakness.

\subsubsection{Lack of railway integration and deficiencies of the Brazilian network}

The railway connection between Campo Grande-Salta-Antofagasta raises the possibility of bulk cargo flow through the Pacific. This variant could be explored if two bridges on the Argentina-Bolivia border were rebuilt and the Belgrano cargos network improved, normalizing rail traffic interrupted a few years ago at Terminal C-15. The weaknesses identified in the use of the road modal could be compensated with the integration of the Brazilian, Bolivian, Argentine and Chilean railway networks (all in metric gauge); 
The West Network has low operating efficiency, which is reflected in reduced speed (15 $\mathrm{km} / \mathrm{h}$ ) and low load capacity. In addition, the non-operation of the Ponta Porã-Indubrasil branch hinders the flow of agricultural production through the Port of Concepción, in Paraguay. This impediment is aggravated by the restriction to the use of "bitrem" (large trucks) in the stretch Ponta Porã-Concepción.

\subsubsection{Governance for the corridor}

The Bio-Oceanic Road corridor established a connection and defined a modal of transport, the road. The private sector seeks to identify business and investment opportunities. The academic centers are also coordinating actions to support the corridor. Despite these advances, the network of agreements is still fragile, as well as incipient contacts of local authorities;

\subsubsection{Mismatch between productivity gains and expansion of the agricultural area and the infrastructure available in the short term}

Logistics chains present transport cost problems and transhipment difficulties between modalities that compromise the natural competitive advantages of Mato Grosso do Sul. These problems are aggravated when the supply of transport does not accompany the increase in production. In occupied areas, increases in production have compromised existing logistics chains, since new agricultural boarders have become more difficult and lack of new infrastructure.

\section{FINAL CONSIDERATIONS}

The Bio-Oceanic Road Corridor has the potential to transform the economic reality of North of Chile, North of Argentina, the Chaco region and Mato Grosso do Sul. In order to achieve such a major objective, it needs to be understood as a platform of national development and not merely as a transport corridor. An infrastructure project to be successful has to take in account the needs and expectations of future users as well as the demands of local communities. The business environment should become suitable to foreign and national investments, the promotion of firm partnerships, improvement of logistics and communication services and strengthen the links between business communities.

We hope that the analytical approach developed through the four sections of this article will enable national, regional and local policy makers to identify and prioritize actions that will focus on the economic and geographical potentials of the four territories, as well as alert them regarding the existence of some weaknesses or threats that need to be tackled immediately by the adoption of the right set of public policies.

In sum, the construction of the Bio-oceanic corridor aims to, not only explore the benefits of the abundance of natural resources and energy or the creation of more jobs for a young and creative labor force, but also provide local trade operators and economic forces with an efficient logistic alternative to traditional gateways to international markets. By doing so, local policy makers will be able to enjoy greater economic and political autonomy and local communities will benefit from more stable jobs. 


\section{REFERENCES}

APEX BRASIL. Mato Grosso do Sul: perfil e oportunidades de exportações e investimentos - 2020. BrasíliaDF: APEX-BRASIL, 2020.

BANCO MUNDIAL. Logística: análisis y opciones para resolver sus desafíos estratégicos. Report n. 54342AR. Argentina: Banco Mundial, 2010.

CASTRO, João Carlos Parkinson. Corredor Rodoviário Bioceânico: novas oportunidades. Dourados, MS, 11 Mar. 2020. [Power Point]. Available at: https://onedrive.live.com/view.aspx?resid=FFA5652B66102A82! 771\&ithint=file\%2cpptx\&authkey=!AH7tlaA13p6-kpQ. Access on: 16 June 2021.

CONSEJO ECONÔMICO SOCIAL. Plan de Logística de la Provincia de Salta. Salta/Argentina: Subsecretaría de Planificación Territorial de la Inversión Pública; Gobierno de la Provincia de Salta; Consejo Económico Social; Corporación Andina de Fomento, Mar. 2016.

ORGANISATION FOR ECONOMIC CO-OPERATION AND DEVELOPMENT [OCDE]. Estudios económicos de Ia OCDE. Chile: OCDE, Feb., 2018. Available at: www.ocde.org./eco/surveys/economic-survey-chile.htm. Access on: 16 June 2021.

UNITED NATIONS CONFERENCE ON TRADE AND DEVELOPMENT (2004-2018). Brazil Liner Shipping Connectivity Index. CEIC, 2018. Available in: https://www.ceicdata.com/en/indicator/brazil/liner-shippingconnectivity-index. Access on: 15 Feb. 2021.

\section{About the author:}

João Carlos Parkinson de Castro: Graduated in Economy at the Pontifical Catholic University of Rio de Janeiro (PUC-Rio). Diplomat, career employee of the Ministry of Foreign Affairs. National coordinator of the Bioceanic Road and Rail Corridors. E-mail: parkinsondecastro54@gmail.com, Orcid: http://orcid.org/0000-0002-7434-9892 